\title{
Epidemiological Study on Hospital Acquired Infections and Infection Prevention and Control among Health Care Workers in Specialist Hospital Bauchi State, Nigeria
}

\author{
Ahmad Salisu Aliyu ${ }^{1, *}$, Ahmed Habibu Badawi ${ }^{1}$, Nuru Yakubu Umar ${ }^{2}$, Funmilayo Abubakar \\ Sani $^{2}$, Bappah Baba Waziri' ${ }^{2}$ \\ ${ }^{l}$ Medical Laboratory Department Infectious Diseases Hospital (IDH) Kano, Nigeria \\ ${ }^{2}$ College of Nursing and Midwifery, Bauchi State, Nigeria
}

*Corresponding Author: Ahmad Salisu Aliyu, Medical Laboratory Department Infectious Diseases Hospital (IDH) Kano, Nigeria, E-mail: salisuahmadaliyu@yahoo.com

\begin{abstract}
Background: Hospital-acquired infections (HAI) are a major public health concern throughout the world, contributing to increased morbidity, mortality, and health care cost. Health care workers (HCWs) are at increased risk of hospital acquired infections transmitted from both blood-borne pathogens. Therefore, the overall aim of this study was to assess the knowledge and practices of health care workers towards Hospital Acquired Infections (HAI) and Infection Prevention and Control (IPC) in Specialist Hospital Bauchi State, Nigeria.
\end{abstract}

Methods: Facility-based cross-sectional study design was conducted among health care workers in Specialist hospital Bauchi State, Nigeria from February, 2020 to April, 2020. Data was collected using a pretested structured questionnaire. Descriptive analysis was performed to obtain the frequency distribution of the variables.

Results: The result shows that 196 participants responded to the questionnaire. The present study showed that, $89.3 \%$ health care workers have knowledge about Hospital Acquired Infection (HAI). According to study participants, most common hospital acquired infections was Respiratory tract infections (30.1\%) and nurses were the most susceptible (34.7\%) group to HAI. Majority of the study participants washed their hands after handling the patients $(92.3 \%)$.

Conclusions: Knowledge about Hospital Acquired Infection is present among health care workers but there is still lack of adequate quality control practice to prevent Hospital Acquired Infection. Importance of prevention of Hospital Acquired Infection should be emphasized among health care workers by intensive information education communication activities. Hand hygiene education should be a mandatory component of all clinical course curricula and should be delivered to health care workers (HCWs) prior to clinical placement.

Keywords: Bauchi, Health care workers (HCWs), Hospital Acquired Infections (HAI), Infection prevention and control (IPC), Nigeria, Quality control,

\section{INTRODUCTION}

Hospital-acquired infections (HAI) are a major public health concern throughout the world, contributing to increased morbidity, mortality, and healthcare cost (Geffers and Gastmeier, 2011). Hospital-acquired infection is defined as a localized or systemic condition that results from adverse reactions to the presence of an infectious agent(s) or its toxin(s), and that occurs 48 hours or more after hospital admission and was not incubating at the time of admission (Garner et al, 1988, Horan and Emori, 1997).

HAI are caused by viral, bacterial, and fungal pathogens. An important predisposing factor to HAIs is the use of instrumentation or devices for intubation, delivery of therapeutic agents, or drainage of body fluids during patient care as supportive measures (Deoine et al, 2009). Healthcare associated bacterial pathogens may well survive or persist on surfaces for months and can thereby be a continuous source of 
transmission if no regular preventive surface disinfection is performed (Axel et al, 2006).

Hospital-acquired infections risk increased with invasive devise used (Deptuła et al, 2015) and a patient in Intensive Care Unit (ICU) (Madani et al, 2009). Incidences of Device-Associated Infections (DAIs) report from International Nosocomial Infection Control Consortium (INICC) are higher than US National Healthcare Safety Network (NHSN) (Dudeck et al, 2015, Rosenthal et al, 2016). The overall DAIs patients indicated that $5.3 \%$ in China (Tao et al, 2011), 12.2\% in Colombia (Moreno et al, 2006) and $13 \%$ in Peruvians ICU patients (Cuellar et al, 2008). Evidences showed that this deviceassociated hospital-acquired infection increases and contribute extra extended length of stay (Vineya et al, 2016, Al-Mousa et al, 2016, Hu et al, 2013), and mortality (Moreno et al, 2006, Cuellar et al, 2008, Hu et al, 2013). Researches in developing countries showed that deviceassociated infections in intensive care unit were high (Jahani-Sherafat et al, 2015, Rasslan et al, 2012) and incurred extra cost for patients (Rosenthal et al, 2015, Higuera et al, 2007, Rosenthal et al, 2003).

Patients admitted in the hospital ward are susceptible to hospital acquired infections. Risk factors are also different from specific site to specific site infections, because hospital environments are complex. Previously conducted researches indicated that, long hospital stays (Al-Rawajfah et al, 2013, Gravel et al, 2007), gender (Deptuła et al, 2015, Durlach et al, 2012), intravascular catheter (Gailienè et al, 2012, Humphreys et al, 2006), surgery since admission (Deptuła et al, 2015, Liu et al, 2016), Intubation (Phu et al, 2016), mechanical ventilation (Oldfield et al, 2009), age of the patient (Yallew et al, 2016, Zhang et al, 2015), type of hospital (Yallew et al, 2016, Xie et al, 2010), urinary catheter (Deptuła et al, 2015, Phu et al, 2016) were some of the risk factors for hospital acquired infections.

According to Centers for Disease Control and Prevention (CDC), healthcare associated infection is defined as "infections acquired during the course of receiving treatment, localized or systemic condition, resulting from an adverse reaction to the presence of an infectious agent(s) or its toxin(s) within a healthcare setting"( CDC/NHSN, 2008).

Nosocomial comes from the Greek word "Nosokomeian", which means a place from which disease is acquired. This definition has been extended to include other forms of healthcare facilities, such as physical and occupational settings. CDC substitutes the word nosocomial infection by healthcare associated infection for surveillance system after developing new definition of healthcare associated infection and criteria for specific types of infections in the acute care setting (CDC/NHSN, 2008).

Infection prevention and control is a central component of safe and high quality service delivery at the facility level (WHO, 2009).With an inadequate practice of infection prevention, the risk of acquiring infections through exposure to blood, body fluids or contaminated materials in healthcare facilities is substantial (FMOH, 2012). In connection with that, contracting an infection while in a healthcare setting challenges the basic idea that healthcare is meant to make people well (Alice et al, 2015). Obviously, lack of compliance with infection prevention and control measures has a number of consequences (CUPE, 2016, Adams et al, 2008).

In recent years, it has been recognized that relatively complex care is increasingly being delivered in the community, including the patient's own home, as well as in acute care hospital settings. The term hospital-acquired infection was used, denoting that an infection was acquired during a hospital admission, and healthcare associated infections which include all infections that develop as a result of healthcare, no matter where the care is delivered (Chand and Nancy, 2014, Prieto et al, 2014).

Health Protection Agency (HPA) in the United Kingdom (UK) and the World Health Organization (WHO) defined healthcare associated infections as "infections acquired in hospital" or "as a result of healthcare interventions". The term HAIs is specifically used for hospital acquired infections, and Community Acquired Infections (CAIs) (WHO, 2009, HPA, 2007). In this article, hospital acquired means infection acquired only in the hospital.

Hospitals are the main health facilities for acquiring infection during delivery of care. There is little evidence concerning the burden of unsafe care in developing countries, where the risk of harm to patients is likely to be greater, due to limitations in infrastructure, technologies, and human resources (Alp et al, 2011). Hospitalrelated infections constitute an important health challenge worldwide. 
Healthcare-associated infection is a major safety issue affecting the quality of care of hundreds of millions of patients every year in both developed and developing countries (Benedetta et al, 2007). According to the WHO national and multicenter literature review, the prevalence of acquiring at least one HCAI ranges from $3.5 \%$ to $12 \%$ among high income countries (WHO, 2011).

In developing countries, the problem reaches up to three times higher compared to the incidence seen in adult intensive care units in USA (Benedetta et al, 2007). According to the WHO review, hospital-wide prevalence of HCAI varies from $5.7 \%$ to $19.1 \%$, with a pooled prevalence of $10.1 \%$ in low income countries (WHO, 2011).

Though there is no regional data in low income countries, a literature review shows that increased length of stay at hospitals is associated with HCAI varying between 5 and 29.5 days (WHO, 2011). In Jordan, the mean Length of Stay (LOS) after infection for cases was 12.1 days (Omar et al, 2012).

Healthcare associated infections are major worldwide public health problems. The Centers for Disease Control and Prevention estimates that 2 million patients suffer from hospitalacquired infections every year and nearly 100,000 of them die (HAI, 2013). HAIs are associated with an increased attributable mortality, length of stay, and healthcare costs incurred by patients, insurers and healthcare facilities (Sheng et al, 2005, Yang et al, 2011). Hospital acquired-infections incur substantial financial burden to the budget of medical institutions, mainly due to additional costs derived from risk factors associated with medical procedures (Gerardo and Citlalyn, 2010).

The burden of health-care-associated infection in developing countries is high. Prevalence of health-care-associated infection is much higher than proportions reported from Europe and the USA. The overall health-care-associated infection density in adult intensive-care units was 47.9 per 1000 patient-days, being at least three times as high as densities reported from the USA (Benedetta et al, 2011). In developing countries, the risk is two to twenty times higher and the proportion of infected patients frequently exceeds $25 \%$ (Pittet et al, 2008). In low and middle income countries, the burden of hospital acquired infections is unknown due to lack of reliable data and the use of different definitions and methodologies (Lul, 201027).

In Africa, literature review shows that hospitalwide prevalence of HAI varies between $2.5 \%$ and $14.8 \%$; in surgical wards, the cumulative incidence ranging from $5.7 \%$ to $45.8 \%$. The largest number of studies focused on surgical site infection, whose cumulative incidence ranges from $2.5 \%$ to $30.9 \%$ (Sepideh et al, 2011). Infrastructure of hospitals, low compliance of hand hygiene, understaffing, overcrowding, heavy workload, misuse of personal protective equipment, late establishment of infection control programmes are major problems in resources limited countries. These problems cause high infection rates and spread of multi-drug resistant pathogens (Emine et al, 2011).

A study show that most hospitals in developing countries especially in Africa, have no effective infection control programmes due to lack of awareness of the problem, lack of personnel, poor water supply, erratic electricity supply, ineffective antibiotic policies with emergence of multiple antibiotic resistant microbes, poor laboratory backup, poor funding and nonadherence to safe practices by health workers (Samuel et al, 2010). In addition infection control and hospital acquired infection prevalence reports are often not well established because of the lack of centralized guidelines, staff and resources (Hall, 1998). In a Moroccan university hospital, almost 2 out of each 10 hospitalized patients contracted a nosocomial infection (Jroundi et al, 2007). Similar results were found in a Tunisian hospital (Kallel et al, 2005).

Infection prevention practice is a serious concern for health care workers; it is a major risk for transmission of infections, such as HIV and hepatitis viruses (Alemie, 2012). In Ethiopia, a research conducted in 10 hospitals and 20 health centers about the behaviors of healthcare workers indicate that, there was a high level of exposure to blood and body fluids among healthcare workers (HCWs) (Ayalu et al, 2010). In addition, there is a lack of up-to-date knowledge, good practices and positive attitudes towards infection prevention in health care settings. HCWs had insufficient knowledge and perception on universal precaution (Ayalu et al, 2010).HCWs are at a very high risk of exposure to blood and body fluids and Poor efforts to prevent infection and wrong practice of 
handling instrument (Gessessew and Kahsu, 2009). Healthcare workers risk may affect all staff at the facility, including nurses, doctors, laboratory technicians, waste management staff and laundry staff.

Globally, hundreds of millions of people are affected every year by avoidable infections in health care (WHO, 2009). In this respect, healthcare associated infections (HCAIs) affect patients, healthcare workers (HCWs), support staff, medical students and patient attendants (FMOH, 2005). The associated burden of disease related to HCAIs is extremely high and the impact of HCAIs implies prolonged hospital stay, long-term disability, and increased resistance of microorganisms to antimicrobials, massive additional financial burden for health systems, high costs for patients and their family, and unnecessary deaths (CUPE, 2016, Adams et al, 2008, Mongolia, 2012). HCAIs accounted for 16 million additional hospital stay in Europe with estimated total costs of $€ 7$ billion, and this also cost the United State healthcare system to loss an estimated \$ 30-45 billion each year. The worldwide estimated indicated more than 1.4 million people are suffering from infections acquired in hospitals. Such risk is 2-20 times higher in developing countries (Allegranzi et al, 2011, Shanelle et al, 2011, WHO, 2010, Tietjen et al, 2003). Despite the simplicity and clarity of precautions; understanding how poor practice could fuel up the transmission, the practice among health care worker is still low. This problem is exacerbated in resource limited settings, like Africa (Gammon et al, 2008, Hu et al, 2012).

Compliance with infection prevention measures is the only way to reduce and protect HCWs, patients and the community from the occurrence of HCAIs and unnecessary injuries (FMOH, 2012). On top of this, various multifaceted factors extremely play a great role to achieve the goal of infection prevention, like adequate knowledge towards infection prevention, availability of personal protective equipments and materials, human power, training, policy and guidelines and essential environmental health conditions (WHO, 2010, FMOH, 2012, Adams et al, 2008, Tietjen et al, 2003). Hence, it is important that HCWs must know and use the recommended infection prevention measures accordingly (FMOH, 2005, Adams et al, 2008, Tietjen et al, 2003, Haileamlak, 2011).
Cognizant of this, no matter what HCAIs can effectively be prevented by applying infection prevention principles, without adequately giving the due attention and assessing the current infection prevention practice of HCWs, it is impossible to enhance infection prevention practice of $\mathrm{HCWs}$, improve quality of service and thereby reduce HCAIs. In addition, there are limited studies in Bauchi State, Nigeria which focused on infection prevention practices of HCWs. Thus, assessing infection prevention practices and identifying associated factors with infection prevention practices among $\mathrm{HCWs}$ is crucial to develop strategies for a successful infection prevention programs and interventions in Bauchi State, Nigeria. Therefore, the overall aim of this study was to assess the knowledge and practices of health care workers towards Hospital Acquired Infections (HAI) and Infection Prevention and Control (IPC) in Specialist Hospital Bauchi State, Nigeria.

\section{Methodology}

\subsection{Study Area And Study Design}

The study was conducted in Specialist Hospital Bauchi State, Nigeria. The hospital has a Medical ward, surgical ward, pediatrics, gynecology, eye clinic and MDRTB. The hospital also has outpatient departments. A facility based cross- sectional study was conducted using interviewer-administered questionnaire from February, 2020 to April, 2020.

\subsection{Sample Size Determination}

In this study, manual calculation of the sample size using Morgan and Krejcie (1970) formula was used for sample size determination as stated below:

$\mathrm{S}=\mathrm{X}^{2} \mathrm{NP}(1-\mathrm{P}) \div \mathrm{d}^{2}(\mathrm{~N}-1)+\mathrm{X}^{2} \mathrm{P}(1-\mathrm{P})$

Where:

$\mathrm{S}=$ Required sample size

$\mathrm{X}^{2}=$ The table value of the chi-square at desired confidence (3.841)

$\mathrm{N}=$ Study Population size (400)

$\mathrm{P}=$ Population proportion assumed to be 0.50 since this would provide maximum sample size

$\mathrm{d}^{2}=$ Degree of accuracy of the result expressed as proportion 0.050

$\underline{3.841 \times 400 \times 0.5 \times 0.5}$ 
Epidemiological Study on Hospital Acquired Infections and Infection Prevention and Control among Health Care Workers in Specialist Hospital Bauchi State, Nigeria

$0.0025 \times 399+3.841 \times 0.5 \times 0.5$

$\underline{384.1}=196$

\subsection{5}

Hence 196 respondents

\subsection{Inclusion and Exclusion Criteria}

The inclusion criteria were all health care workers working at the hospital and willing to participate in the study and Hospital workers who do not deal directly with touching patients, and those whose mandate is not patient care were excluded from the study.

\subsection{Data collection}

Data was collected from eligible and willing participants using a pre-tested, structured questionnaire. The participants were given clear instructions of filling the questionnaire. It took roughly about 20-25 minutes to fill in the questionnaire. The participants were followed in their respective departments (work place) during morning and afternoon shifts.

\subsection{Data Analysis}

Data were analyzed using Statistical Package for Social Science (SPSS) software version 16.0 at that time with the help of the Statistician. The descriptive statistical method was used to analyze frequencies and percentages.

\subsection{Ethical Considerations}

This study was conducted only After getting Approval from Ministry of Health Bauchi State, data collectors was informed about the study, then after Verbal and written Informed consent obtained from study subjects, Confidentiality was assured for all the information provided, no personal identifiers (anonymity) was used on the questionnaires.

\section{RESULTS}

A total of 196 Health Care Workers (HCWs) were interviewed, giving $100 \%$ response rate. Of the study subjects, 152(77.6\%) and 44(22.4\%) were males and females respectively. Among all, 98(50\%) of HCWs were 30-39 years of age. $62(31.6 \%)$ of HCWs were single, $123(62.8 \%)$ currently married. $8(4.1 \%)$ divorced and $3(1.5 \%)$ HCWs were widowed (Table 1). The socio-economic characteristics of the study showed that, among all HCWs, $8(4.1 \%)$ of HCWs were Doctors 20(10.2\%) of HCWs were Medical Lab Scientist, 48(24.5\%) of HCWs were Nurses, $18(9.2 \%)$ of HCWs were Pharmacist, 27(13.8\%) of HCWs were Primary Health Care, $15(7.6 \%)$ of HCWs were X-ray, and others were 60(30.6\%). Among all,
67(34.2\%) of HCWs were 11-15 years of working experience (Table 1).

Table 1. Socio demographic characteristics of the study population $(n=196)$

\begin{tabular}{|l|l|l|}
\hline Characteristics & Frequencies & \multicolumn{1}{|c|}{$\begin{array}{c}\text { Percentages } \\
(\%)\end{array}$} \\
\hline Gender & 152 & 77.6 \\
\hline Males & 44 & 22.4 \\
\hline Females & 76 & 38.8 \\
\hline Ages & 98 & 50 \\
\hline $20-29$ & 18 & 9.2 \\
\hline $30-39$ & 4 & 2.0 \\
\hline $40-49$ & & \\
\hline $50+$ & 123 & 62.8 \\
\hline Marital Status & 62 & 31.6 \\
\hline Married & 8 & 4.1 \\
\hline Single & 3 & 1.5 \\
\hline Divorce & & \\
\hline Widowed & 8 & 4.1 \\
\hline Profession & 20 & 10.2 \\
\hline Medical Doctors & & \\
\hline $\begin{array}{l}\text { Medical Lab } \\
\text { Scientist }\end{array}$ & 48 & 24.5 \\
\hline Nurses & 18 & 9.2 \\
\hline Pharmacist & 27 & 13.8 \\
\hline $\begin{array}{l}\text { Primary Health } \\
\text { Care }\end{array}$ & & 7.6 \\
\hline x-ray & 15 & 30.6 \\
\hline Others & 60 & 20.4 \\
\hline Work Experience & & 25.5 \\
\hline 1-5yrs & 40 & 34.2 \\
\hline 6-10yrs & 50 & 19.9 \\
\hline 11-15yrs & 67 & 39 \\
\hline 16yrs+ & 39 \\
\hline The present & & \\
\hline
\end{tabular}

The present study showed that, $89.3 \%$ healthcare workers have knowledge about Hospital Acquired Infection (HAI). According to study participants, most common hospital acquired infections was Respiratory tract infection $(30.1 \%)$ followed by gastrointestinal infection $(21.9 \%)$ and nurses were the most susceptible (34.7\%) group to HAI followed by Cleaners (27.5\%). Among the study participants, $90.8 \%$ had knowledge about prevention of hospital acquired infection. Hand washing was the most common method to prevent hospital acquired infections (61.7\%) followed by personal protective equipment (24\%). Present study showed, 94.4\% of the study participants knew about recognized sources of hospital acquired infections. Most common recognized sources of hospital acquired infections was mattresses and pillows $(39.3 \%)$ followed by white coat (23\%), thermometer (16.3\%), mobile phones (14.3\%), (Table 2). 
Epidemiological Study on Hospital Acquired Infections and Infection Prevention and Control among Health Care Workers in Specialist Hospital Bauchi State, Nigeria

Table 2. Knowledge of study participants towards hospital acquired infections $(n=196)$

\begin{tabular}{|c|c|c|}
\hline Characteristics & $\begin{array}{c}\text { Frequenci } \\
\text { es }\end{array}$ & $\begin{array}{c}\text { Percentages } \\
(\%)\end{array}$ \\
\hline $\begin{array}{ll}\text { Knowledge } & \text { about } \\
\text { commonly } & \text { found } \\
\text { infections } & \\
\end{array}$ & & \\
\hline Yes & 175 & 89.3 \\
\hline No & 21 & 10.7 \\
\hline $\begin{array}{l}\text { Commonly seen hospital } \\
\text { acquired infection }\end{array}$ & & \\
\hline Urinary tract infection & 31 & 15.8 \\
\hline Respiratory tract infection & 59 & 30.1 \\
\hline Surgical wound infection & 29 & 14.8 \\
\hline Blood borne infection & 19 & 9.7 \\
\hline $\begin{array}{l}\text { Skin and soft tissue } \\
\text { infection }\end{array}$ & 15 & 7.7 \\
\hline Gastrointestinal infection & 43 & 21.9 \\
\hline $\begin{array}{l}\text { Most susceptible group to } \\
\text { hospital } \\
\text { infections }\end{array}$ & & \\
\hline Doctors & 8 & 4.1 \\
\hline Nurses & 68 & 34.7 \\
\hline Cleaners & 54 & 27.5 \\
\hline Medical Lab Scientist & 18 & 9.2 \\
\hline Others & 48 & 24.5 \\
\hline \multicolumn{3}{|l|}{$\begin{array}{l}\text { Knowledge of methods to } \\
\text { prevent HAIs }\end{array}$} \\
\hline Yes & 178 & 90.8 \\
\hline No & 18 & 9.2 \\
\hline \multicolumn{3}{|l|}{$\begin{array}{|llr|}\text { Methods } & \text { to } & \text { prevent } \\
\text { hospital } & & \text { acquired } \\
\text { infections } & & \end{array}$} \\
\hline Hand washing & 121 & 61.7 \\
\hline $\begin{array}{l}\text { Personal protective } \\
\text { equipment }\end{array}$ & 47 & 24 \\
\hline Use of antibiotics & 8 & 4.1 \\
\hline
\end{tabular}

\begin{tabular}{|l|c|c|}
\hline vaccination of infected & 20 & 10.2 \\
patients & & \\
\hline $\begin{array}{l}\text { Knowledge of any } \\
\text { recognized sources of } \\
\text { hospital acquired } \\
\text { infections }\end{array}$ & & \\
\hline Yes & 185 & 94.4 \\
\hline No & 11 & 5.6 \\
\hline Recognized sources of & & \\
infections & & \\
\hline Mattresses and pillows & 77 & 39.3 \\
\hline White coat & 45 & 23 \\
\hline Thermometer & 32 & 16.3 \\
\hline Mobile phones & & \\
\hline Bed side curtains & & \\
\hline Stethoscope & & \\
\hline
\end{tabular}

Almost all, 193(98.5\%) reported that they knew what an 'infection' means, while $3(1.5 \%)$ replied that they still feel vague regarding the proper definition of 'infection'. Similarly, $189(96.4 \%)$ claimed that they knew the preventives measures of infectious diseases, while $7(3.6 \%)$ were of the view that they were still not well versed with prevention of infectious disease. Regarding practices for infection control or standard precautions for prevention of infection, 185(94.4\%) reported that they came across this concept during their student life. All of them were of the view that hand hygiene / hand washing is one of the practices for infection control and standard precaution for prevention of infection, and $195(99.5 \%)$ of them added that use of personal protective equipment (PPE) is also considered as standard protocol for infection control. Similarly, 190(96.9\%) felt that handling a patient can be a source of infection. A similar proportion of the study participants reported that they wear gloves when touching blood or secretion of an infected patient. All of them also agreed that everybody should use gown / plastic apron while attending surgical procedures. Apart from the hand washing and wearing of personal protective equipment (PPE) 92(46.9\%) observed additional measures or transmission based precautions while attending isolated high- 
risk patients. 97(49.5\%) responded that they know about infection control, while 99(50.5\%)were of the view that they still need reading in this regard. Similarly, 196(100\%) considered that increase in awareness about infection prevention and control is beneficial for community (Table 3 ).

Table 3. Knowledge of infection prevention and control as reported by respondents $(n=196)$

\begin{tabular}{|c|c|c|}
\hline Characteristics & Yes (\%) & No $(\%)$ \\
\hline $\begin{array}{l}\text { Do you know what an } \\
\text { infection is? }\end{array}$ & $193(98.5 \%)$ & $3(1.5 \%)$ \\
\hline \begin{tabular}{|l|} 
Do you know what \\
infection prevention is?
\end{tabular} & $189(96.4 \%)$ & $7(3.6 \%)$ \\
\hline $\begin{array}{l}\text { Have you ever heard about } \\
\text { infection control practices } \\
\text { or standard precaution for } \\
\text { prevention of infection? }\end{array}$ & $185(94.4 \%)$ & $11(5.6 \%)$ \\
\hline $\begin{array}{l}\text { Do you think hand } \\
\text { hygiene / hand washing } \\
\text { can reduce chances of } \\
\text { getting infection? }\end{array}$ & $196(100 \%)$ & $0(0.0 \%)$ \\
\hline $\begin{array}{lr}\text { Do you know } & \text { about PPE } \\
\text { (personal } & \text { protective } \\
\text { equipment)? } & \end{array}$ & $195(99.5 \%)$ & $1(0.5 \%)$ \\
\hline $\begin{array}{l}\text { Do you think handling a } \\
\text { patient can be a source of } \\
\text { infection? }\end{array}$ & $190(96.9 \%)$ & $6(3.1 \%)$ \\
\hline $\begin{array}{l}\text { Do you wear gloves when } \\
\text { touching blood or } \\
\text { secretion of an infected } \\
\text { patient? }\end{array}$ & $195(99.5 \%)$ & $1(0.5 \%)$ \\
\hline $\begin{array}{|llr|}\text { Do you } & \text { wear } & \text { gown } \\
\text { plastic } & \text { apron } & \text { while } \\
\text { attending } & & \text { surgical } \\
\text { procedure? } & & \\
\end{array}$ & $196(100 \%)$ & $0(0.0 \%)$ \\
\hline \begin{tabular}{|lr} 
Have & you ever observed \\
any additional & or \\
transmission & based \\
precautions & while \\
attending isolated & high- \\
risk patients? & \\
\end{tabular} & 92(46.9\%) & $104(53.1 \%)$ \\
\hline $\begin{array}{l}\text { Have you ever come } \\
\text { across any information } \\
\text { regarding infection control } \\
\text { practices? }\end{array}$ & $97(49.5 \%)$ & $99(50.5 \%)$ \\
\hline $\begin{array}{l}\text { Spreading awareness } \\
\text { about infection prevention } \\
\text { and control is beneficial } \\
\text { for community? }\end{array}$ & 196(100\%) & $0(0.0 \%)$ \\
\hline
\end{tabular}

The present study showed, $89.3 \%$ of the study population used reusable instruments and $64.8 \%$ of the study population used pre-sterilized instruments. $91.8 \%$ of the study participants soak reusable medical instruments in chlorine solution. The present study also showed, 91.3\% cover their nose and mouth while sneezing in the hospital ward and $67.9 \%$ used masks before approaching patients. It was seen that, $92.3 \%$ of the study participants washed their hands after handling the patients but $18.9 \%$ of the study participants had history of touching of eyes, nose and mouth while handling patients. Practice of cleaning of white coat or nursing uniform regularly was seen among $75.5 \%$ of study participants.

The present study showed, $46.4 \%$ of the study participants previously had exposure to patient's blood, vomit or other body. $84.2 \%$ of the study participants mix dry and liquid healthcare wastes, however, $94.4 \%$ of the study participants incinerate or bury used sharp materials. The present study showed, $79.1 \%$ of the study participants practice high-level disinfection where sterilization is not applicable (Table 4).

Table 4. Practice of study participants towards hospital acquired infections and Infection Prevention control $(n=196)$

\begin{tabular}{|l|c|c|}
\hline \multicolumn{1}{|c|}{ Characteristics } & Frequencies & $\begin{array}{c}\text { Percentages } \\
(\%)\end{array}$ \\
\hline $\begin{array}{l}\text { Practices of using of the } \\
\text { reusable instruments }\end{array}$ & & \\
\hline Yes & 175 & 89.3 \\
\hline No & 21 & 10.7 \\
\hline $\begin{array}{l}\text { Do you soak reusable } \\
\text { medical instruments in } \\
\text { chlorine solution? }\end{array}$ & & \\
\hline Yes & 180 & 91.8 \\
\hline No & 16 & 8.2 \\
\hline $\begin{array}{l}\text { Practices of using of } \\
\text { pre-sterilized } \\
\text { instruments }\end{array}$ & & \\
\hline Yes & 127 & 64.8 \\
\hline No & 69 & 35.2 \\
\hline $\begin{array}{l}\text { Covering of nose and } \\
\text { mouth during Sneezing }\end{array}$ & & \\
\hline Yes & 179 & 91.3 \\
\hline No & 17 & 8.7 \\
\hline $\begin{array}{l}\text { Use of mask before } \\
\text { approaching a patient }\end{array}$ & & \\
\hline Yes & 133 & 67.9 \\
\hline No & 63 & 32.1 \\
\hline $\begin{array}{l}\text { Washing of hands after } \\
\text { handling every patient }\end{array}$ & & \\
\hline Yes & 181 & 92.3 \\
\hline No & 15 & 7.7 \\
\hline $\begin{array}{l}\text { Touching of eyes, nose } \\
\text { and mouth while } \\
\text { handling Patients }\end{array}$ & & \\
\hline Yes & & \\
\hline No & & \\
\hline $\begin{array}{l}\text { Practice of cleaning of } \\
\text { white coat or nursing }\end{array}$ & & 81.1 \\
\hline
\end{tabular}




\begin{tabular}{|c|c|c|}
\hline \multicolumn{3}{|l|}{$\begin{array}{l}\text { uniform regularly after } \\
\text { hospital duty }\end{array}$} \\
\hline Yes & 148 & 75.5 \\
\hline No & 48 & 24.5 \\
\hline \multicolumn{3}{|l|}{$\begin{array}{l}\text { Exposure of study } \\
\text { participants to patient's } \\
\text { blood, vomit or other } \\
\text { bodily fluids }\end{array}$} \\
\hline Yes & 91 & 46.4 \\
\hline \begin{tabular}{|l|l|} 
No \\
\end{tabular} & 105 & 53.6 \\
\hline \multicolumn{3}{|l|}{$\begin{array}{l}\text { Did you mix dry and } \\
\text { liquid } \\
\text { wastes? }\end{array}$} \\
\hline \begin{tabular}{|l|l|} 
Yes \\
\end{tabular} & 165 & 84.2 \\
\hline No & 31 & 15.8 \\
\hline \multicolumn{3}{|l|}{$\begin{array}{l}\text { Do you incinerate or } \\
\text { bury used sharp } \\
\text { materials? }\end{array}$} \\
\hline \begin{tabular}{|l|l|} 
Yes \\
\end{tabular} & 185 & 94.4 \\
\hline No & 11 & 5.6 \\
\hline \multicolumn{3}{|l|}{$\begin{array}{l}\text { Did you practice } \\
\text { level disinfection } \\
\text { levere } \\
\text { sterilization is } \\
\text { applicable? }\end{array}$} \\
\hline Yes & 155 & 79.1 \\
\hline No & 41 & 20.9 \\
\hline
\end{tabular}

\section{DISCUSSION}

The present study showed that, $89.3 \%$ health care workers have knowledge about Hospital Acquired Infection (HAI) which is almost similar to a study done by Ocran and Tagoe, 2014 in Ghana, where they found $88.7 \%$ Health Care Workers (HCWs) had some knowledge of HAIs. Respiratory tract infection (30.1\%) followed by gastrointestinal infection (21.9\%) were the two most common hospital acquired infections according to study participants which similar from a study conducted by Sheth et al, 2017 in Gujarat where $98.8 \%$ of study participants unanimously acknowledged respiratory tract infection to be the most common HAI. Among the study participants, 90.8\% had knowledge about prevention of hospital acquired infection which is slightly similar than a study done by Ogonia et al, 2015 in Nigeria (91.6\%).

Hand washing was the most common method to prevent hospital acquired infections (61.7\%) followed by personal protective equipment (24\%). According to Pittet and Boyce, 2003, five moment of hand hygiene should be performed before touching a patient, before aseptic / clean procedure, after body fluid exposure risk, after touching a patient and after touching patient surroundings. The WHO, 2005
Guidelines on Hand Hygiene in Health Care provider healthcare workers states that, with a thorough review of evidence on hand hygiene in health care and specific recommendations to improve practices and reduce the transmission of pathogenic microorganisms to patients and HCWs. The WHO "SAVE LIVES: Clean Your Hands" programme reinforces the "My 5 Moments for Hand Hygiene" approach as key to protect the patients; HCWs and the health-care environment against the spread of pathogens and thus reduce Healthcare- associated infections (HAIs). This approach encourages HCWs to clean their hands: before touching a patient, before clean/aseptic procedures, after body fluid exposure/risk, after touching a patient and after touching patient surroundings [WHO, 2005]. Katowa et al, 2006 reported that multimodal strategies have been shown to be more successful in improving rates of adherence with hand hygiene in HCWs than single interventions, e.g. Multi-faceted approaches focusing on system change, administrative support, motivation, availability of alcoholbased hand rubs, training and intensive education of HCWs and reminders in the workplace have been recommended for improvement in hand hygiene. There should also be adequate supply of hand hygiene products, lotions and creams, disposable towels and facilities for hand washing, where necessary Alcohol hand rubs should be available at the point of care in sufficient quantities (Pittet et al, 2004).

The present study showed, $64.8 \%$ of the study population used pre-sterilized instruments which are much higher than a study conducted by Ocran and Tagoe, 2014 in Ghana where only $25.4 \%$ were using pre-sterilized medical instruments. Studies indicate that healthcare workers hands are the main source of HAI transmission, and therefore, hand washing by caregivers is the most important procedure in preventing HAIs (Kampf and Kramer, 2004). Present study showed that, $92.3 \%$ of the study participants washed their hands after handling the patients which is higher than a study done by Ogoina et al, 2015 in Nigeria (58.5\%) and Paudyal Pet al, 2008 among Nepalese healthcare workers (70\%). Mohammad zadeh et al, 2013 in Iran found, the highest correct answer (87.5\% of respondents) was to a question about washing hands after accidental contact with blood, liquids and secretions of patients. 


\section{CONCLUSION}

The present study showed majority of the health care workers have knowledge about hospital acquired infections and infection prevention and control but there is still lack of adequate quality control practice to prevent hospital acquired infection. The study emphasizes on the need for adequate knowledge and maintenance of proper hygiene by heath care workers especially nurses in reducing the incidences of hospital acquired infections. The study also highlights use of different preventive methods such as handwashing, disposal of wastes, sterilization of instruments, use of protective equipment's like apron, gloves, masks, shoes etc practiced by health care workers while working in the hospital. Most of the health care workers are willing to change their working environment instead of following standard precautions against Hospital Acquired Infection. The fear of getting infected from patients may compromise quality health care service to patients.

\section{RECOMMENDATIONS}

There is a need for regular trainings among health care workers with regard to hand hygiene. There is need to Periodically monitor and record adherence as the number of handhygiene episodes performed by personnel and or number of hand-hygiene opportunities, by ward or by service. Provide feedback to personnel regarding their performance. Hand hygiene education should be a mandatory component of all clinical course curricula and should be delivered to health care workers (HCWs) prior to clinical placement. Adherence to appropriate hand hygiene should be assessed periodically. Hand hygiene programs and continuous quality improvement are necessary: continuous quality improvement process and hand hygiene program. Hand hygiene campaigns should be conducted more often is essential. Hand hygiene Posters to be changed frequently to attract health care workers attention. Importance of information education communication to prevent Hospital Acquired Infection should be emphasized among health care workers.

\section{ACKNOWLEDGMENTS}

I am grateful to thank the study participants (HCWs) and acknowledge the team of research assistants.

\section{REFERENCES}

[1] Adams J, Bartram J, Chartier Y. (2008) Essential Environmental Health Standards in
Health Care. Geneva, Switzerland: WHO; (2008)

[2] Alemie GA. (2012) Exploration of healthcare workers' perceptions on occupational risk of HIV transmission at the University of Gondar Hospital, Northwest Ethiopia. BMC Res Notes. (2012) Dec 29; 5:704.

[3] Allegranzi.B, Bagheri Nejab.S, Combescure. C, Graafmans.W, Attar.H et al. (2011) Burden of endemic health-care-associated infection in developing countries: systematic review and meta-analysis. Lancet.(2011);377(9761):22841.doi:http://dx.doi.org/10.1016/S01406736(1 0)61458-4.

[4] Alice WG, Simon MK, Elijah N, Z.Ngalo OA.(2015) Health Care Workers Adherence to Infection Prevention Practices and Control Measures: A Case of a Level Four District Hospital in Kenya. American Journal of Nursing Science. (2015); 4 (2): 39-44. doi:10.11648/j.ajns.(2015) 0402.13.

[5] Al-Mousa HH, Omar AA, Rosenthal VD, Salama MF, Aly NY, El-Dossoky Noweir M, et al. (2016) Device-associated infection rates, bacterial resistance, length of stay, and mortality in Kuwait: International Nosocomial Infection Consortium findings. Am J Infect Control. (2016) ; 44: 444-449. doi:10.1016/ j.ajic.2015.10.031.

[6] Alp E, Leblebicioglu H, Doganay M, Voss A. (2011) Infection control practice in countries with limited resources. Ann Clin Microbiol Antimicrob. (2011) Oct 22;10:36.

[7] Al-Rawajfah OM, Cheema J, Hewitt JB, Hweidi IM, Musallam E. (2013) Laboratoryconfirmed, health care associated bloodstream infections in Jordan: a matched cost and length of stay study. Am J Infect Control. (2013); 41: 607-611. doi:10.1016/j.ajic.2012.08.014.

[8] Axel Kramer, Ingeborg Schwebke, Günter Kampf. (2006) How long do nosocomial pathogens persist on inanimate surfaces? A systematic review. BMC Infectious Diseases. (2006) ;6(30).

[9] Ayalu A. Reda, Shiferaw Fisseha, Bezatu Mengistie, Jean-Michel Vandeweerd. (2010) Standard Precautions: Occupational Exposure and Behavior of Health Care Workers in Ethiopia. PLoS ONE. 2010;5(12):e14420.

[10] Benedetta Allegranzi, Julie Storr, Gerald Dziekan, Agn`es Leotsakos, Liam Donaldson, Didier Pittet. (2007) The First Global Patient Safety Challenge "Clean Care is Safer Care": from launch to current progress and achievements. Journal of Hospital Infection. (2007) ;65 (s2):115-123.

[11] Benedetta Allegranzi, Sepideh Bagheri Nejad, Christophe Combescure, Wilco Graafmans, 
Homa Attar, Liam Donaldson, et al. (2011) Burden of endemic health-care-associated infection in developing countries: systematic review and meta-analysis. Lancet. (2011) ;377:228-241.

[12] Canadian Union of Public Employees (CUPE) (2016) Healthcare acquired infections: A backgrounder (2009). Accessed January 13, (2016) Available at: https://cupe.ca/sites/ cupe/ files/ health care associated- infections-cupebackgrounder.pdf

[13] CDC/NHSN. CDC/NHSN (2008) surveillance definition of health care-associated infection and criteria for specific types of infections in the acute care setting. Am Journal Infect Control. (2008) ;(36):309-32.

[14] Chand Wattal, Nancy Khardori. (2014) Hospital Infection Prevention: Principles \& Practices. New Delhi: Springer India; (2014).

[15] Cuellar LE, Fernandez-Maldonado E, Rosenthal VD, Castaneda-Sabogal A, Rosales R, Mayorga-Espichan MJ, et al. (2008) Device-associated infection rates and mortality in intensive care units of Peruvian hospitals: findings of the International Nosocomial Infection Control Consortium. Rev Panam Salud Pública. (2008) ;24:16-24. doi:10.1590/S1020 49892008000700002.

[16] Deoine Reed, Sandra A. Kemmerly. (2009) Infection Control and Prevention: A Review of Hospital-Acquired Infections and the Economic Implications. The Ochsner Journal. (2009) ;9(1):27-31.

[17] Deptuła A, Trejnowska E, Ozorowski T, Hryniewicz W. (2015) Risk factors for healthcare-associated infection in light of two years of experience with the ECDC point prevalence survey of healthcare-associated infection and antimicrobial use in Poland. $\mathbf{J}$ Hosp Infect. (2015) ; 90: 310-315. doi:10.1016/ j.jhin.2015.03.005.

[18] Dudeck MA, Edwards JR, Allen-Bridson K, Gross C, Malpiedi PJ, Peterson KD, et al. (2015) National Healthcare Safety Network report, data summary for 2013, Deviceassociated Module. Am J Infect Control. 2015;43: 206-221. doi:10.1016/ j.ajic.2014 .11 .014 .

[19] Durlach R, McIlvenny G, Newcombe RG, Reid G, Doherty L, Freuler C, et al. (2012) Prevalence survey of healthcare-associated infections in Argentina; comparison with England, Wales, Northern Ireland and South Africa. J Hosp Infect. (2012); 80: 217-223. doi:10.1016/j.jhin.2011.12.001.

[20] Emine Alp, Hakan Leblebicioglu, Mehmet Doganay, Andreas Voss. (2011) Infection control practice in countries with limited resources. Annals of Clinical Microbiology and Antimicrobials [Internet]. 2011;10(36). Available from: http://www.annclinmicrob.com/content/10/1/36

[21] Federal Ministry of Health of Ethiopia (2005). National Infection Prevention Guidelines for Health care Facilities in Ethiopia. 1sted. Addis Ababa, Ethiopia: Disease Prevention and Control Department; (2005).

[22] Federal Ministry of Health of Ethiopia (2012). Infection prevention and patient safety reference manual for service providers and managers in healthcare facilities of Ethiopia. 2nd ed. Addis Ababa, Ethiopia: Federal Ministry of Health; (2012).

[23] Gailienė G, Gierasimovič Z, Petruševičienè D, Macijauskienè A. (2012) The prevalence of health care-associated infections and risk factors in a university hospital. Med Kaunas Lith. 2012;48: 399-403.

[24] Gammon J, Morgan-Samuel H, Gould D. (2008) A review of the evidence for suboptimal compliance of healthcare practitioners to standard/universal infection control precautions. Journal of Clinical Nursing. (2008); 17:157-167.

[25] Garner JS, Jarvis WR, Emori TG, Horan TC, Hughes JM.(1988) CDC definitions for nosocomial infections, (1988). American Journal of Infection Control. (1988) Jun; 16(3):128-40.

[26] Geffers C, Gastmeier P. (2011) Nosocomial infections and multidrug-resistant organisms in Germany: epidemiological data from KISS (the Hospital Infection Surveillance System). Dtsch Arztebl Int. (2011) Feb;108(6):87-93.

[27] Gerardo Álvarez-Hernández, Citlalyn AmaroOrtega. (2010) Attributable costs and risk factors for nosocomial infection in a pediatric Hospital of Sonora, Mexico: (2008) . Bol Med Hosp Infant Mex. (2010);67:116-25.

[28] Gessessew A, Kahsu A. (2009) Occupational exposure of health workers to blood and body fluids in six hospitals of Tigray region (August 1-30, 2006): magnitude and management. Ethiopan Mededical Journal. (2009); 47(3):213-9.

[29] Gravel D, Taylor G, Ofner M, Johnston L, Loeb M, Roth V, et al. (2007) Point prevalence survey for health care associated infections within Canadian adult acute-care hospitals. J Hosp Infect. (2007) ; 66: 243-248. doi:10.1016/j.jhin.2007.04.008.

[30] Haileamlak A, Editorial: (2011) Preventing health care associated infections. Ethiop Journal of Health Sciences. (2011); 21(1):7-8.

[31] Hall A. Editorial: (1998) Nosocomial infection in developing countries: time to learn. Tropical Medicine \& International Health. (1998) ;3(7):517-517. 
[32] Healthcare-Associated Infection Working Group of the Joint Public Policy Committee. Essentials of Public Reporting of HealthcareAssociated Infections: A Tool [Internet]. Centers for Disease Control and Prevention Web site. [Cited 2013 Feb 12]. Available from http://www.cdc.gov/ncidod/dhqp/pdf/ar/06_10 7498_Essentials_Tool_Kit.pdf.

[33] Health Protection Agency (2007). Health care associated infections. London; (2007).

[34] Higuera F, Rangel-Frausto MS, Rosenthal VD, Soto JM, Castañon J, Franco G, et al. (2007) Attributable cost and length of stay for patients with central venous catheter-associated bloodstream infection in Mexico City intensive care units: a prospective, matched analysis. Infect Control Hosp Epidemiol. (2007) ; 28: 31-35. Doi: 10.1086/510812.

[35] Horan TC, Emori TG. (1997) Definitions of key terms used in the NNIS System. American Journal of Infection Control. (1997) Apr; 25(2):112-6.

[36] Hu TA, Anh NQ, Chau NQ, Hung NV.(2012) Knowledge, Attitude and Practices Regarding Standard and Isolation Precautions Among Vietnamese Health Care Workers: A Multicenter Cross-Sectional Survey. Intern Med. (2012); 2:115. doi:10.4172/21658048.1000115.

[37] Hu B, Tao L, Rosenthal VD, Liu K, Yun Y, Suo Y, et al. (2013) Device-associated infection rates, device use, length of stay, and mortality in intensive care units of 4 Chinese hospitals: International Nosocomial Control Consortium findings. Am J Infect Control. (2013); 41:301-306.doi:10.1016/ j.ajic. 2012 .03.037.

[38] Humphreys H, Newcombe RG, Enstone J, Smyth ETM, McIlvenny G, Fitzpatrick F, et al. (2008) Four country health care associated infection prevalence survey (2006): risk factor analysis. J Hosp Infect. (2008) ; 69: 249-257. doi:10.1016/j.jhin.2008.04.021.

[39] Jahani-Sherafat S, Razaghi M, Rosenthal VD, Tajeddin E, Seyedjavadi S, Rashidan M, et al. (2015) Device associated infection rates and bacterial resistance in six academic teaching hospitals of Iran: Findings from the International Nocosomial Infection Control Consortium (INICC). J Infect Public Health. (2015);8: 553-561.doi:10.1016/j.jiph. 2015 .04 .02813 .

[40] Jroundi I, Khoudri I, Azzouzi A, Zeggwagh AA, Benbrahim NF, Hassouni F, et al. (2007) Prevalence of hospital- acquired infection in a Moroccan university hospital. Am J Infect Control. (2007) Aug;35(6):412-6.

[41] Kallel H, Bahoul M, Ksibi H, Dammak H, Chelly H, Hamida CB, et al. (2005) Prevalence of hospital-acquired infection in a Tunisian hospital. J Hosp Infect. (2005) Apr;59(4):3437.

[42] Kampf G, Kramer A. (2004). Epidemiologic background of hand hygiene and evaluation of the most important agents for scrubs and rubs. Clin Microbiol Rev. (2004); 17:863-93.

[43] Katowa, P., Mukwato, M., Ngoma, Maimbolwa. (2006). Compliance with Infection Prevention Guidelines by Health Care Workers at Ronald Ross General Hospital Mufulira District: Department of Post Basic Nursing, School of Medicine, University of Zambia, Lusaka: Zambia.

[44] Liu JY, Wu YH, Cai M, Zhou CL. (2016) Point-prevalence survey of healthcareassociated infections in Beijing, China: a survey and analysis in (2014). J Hosp Infect. (2016) ;93: 271-279. doi:10.1016/ j.jhin. 2016.03.019.

[45] Lul Raka. (2010) Prevention and Control of Hospital-Related Infections in Low and Middle Income Countries. The Open Infectious Diseases Journal. (2010);(4):12531.

[46] Madani N, Rosenthal VD, Dendane T, Abidi K, Zeggwagh AA, Abouqal R. (2009) .Healthcare associated infections rates, length of stay, and bacterial resistance in an intensive care unit of Morocco: Findings of the International Nosocomial Infection Control Consortium (INICC). Int Arch Med. (2009) ;2: 29. doi:10.1186/1755-7682-2-29.

[47] Mohammad zadeh M, Behnaz F, Parsa S. (2013). Knowledge, practice and attitude towards standard isolation precautions in nurses, auxiliary nurses and midwives of Shahid Sadoughi Hospital, Yazd, Iran. Int J Infect Control. (2013); 9(i):1-8.

[48] Mongolia: (2012). Fifth Health Sector Development Project. Subsector Analysis (Summary): Hospital Hygiene and Infection Prevention and Control. (2012). Accessed October 25, (2015) Available at https:// www.adb.org/ sites/default/files/linked. /45009 -002-mon-oth-03.pdf.

[49] Morgan, DW and Krejcie, RV. (1970). Determining Sample size for research activities of Minnesota: USA.

[50] Moreno CA, Rosenthal VD, Olarte N, Gomez WV, Sussmann O, Agudelo JG, et al. (2006) Device-associated infection rate and mortality in intensive care units of 9 Colombian hospitals: findings of the International Nosocomial Infection Control Consortium. Infect Control Hosp Epidemiol. (2006) ; 27: 349-356. doi:10.1086/503341.

[51] Ocran I, Tagoe DN. (2014). Knowledge and attitude of healthcare workers and patients on 
healthcare associated infections in a regional hospital in Ghana. Asian Pacific J Trop Dis. (2014) Apr; 4(2):135-9.

[52] Oldfield MM, El-Masri MM, Fox-Wasylyshyn SM. (2009) Examining the association between chest tube-related factors and the risk of developing healthcare-associated infections in the ICU of a community hospital: a retrospective case-control study. Intensive Crit Care Nurs. (2009) ; 25: 38-44. doi:10.1016/ j.iccn.(2008) .07.001.

[53] Ogoina D, Pondei K, Adetunji B, Chima G, Isichei C, Gidado S. (2015). Knowledge, attitude and practice of standard precautions of infection control by hospital workers in two tertiary hospitals in Nigeria: a cross-sectional study. J Infection Prevention. (2015) ; 16(1):16-22.

[54] Omar M. AL-Rawajfah, Jehanzeb Cheema, Issa M. Hweidi, Jeanne Beauchamp Hewitt, Eyad Musallam. (2012) Laboratory confirmed health care-associated bloodstream infections: A Jordanian study. Journal of Infection and Public Health. (2012);(5):403-411.

[55] Paudyal P, Simkhada P, Bruce J. (2008). Infection control knowledge, attitude and practice among Nepalese health care workers: a survey based study. Am J Infect Control. October (2008) ; 36(8):595-7.

[56] Phu VD, Wertheim HFL, Larsson M, Nadjm B, Dinh Q-D, Nilsson LE, et al. (2016) Burden of Hospital Acquired Infections and Antimicrobial Use in Vietnamese Adult Intensive Care Units. PloS One. (2016); 11: e0147544. doi:10.1371/ journal.pone.01475 4414.

[57] Pittet and Boyce. (2003). Revolutionizing hand hygiene in health-care settings: guidelines revisited. Geneva: Switzerland.

[58] Pittet D., Simon, A., Hugonnet, S., PessoaSilva, CL., Sauvan, V.\&, Perneger, TV., (2004) Hand hygiene among physicians: performance, beliefs, and perceptions. Geneva: Switzerland

[59] Pittet, D. Allegranzi, B. Storr, J. Bagheri, S. Nejad, G. Dziekan, A. Leotsakos, et al. (2008) Infection control as a major World Health Organization priority for developing countries. Journal of Hospital Infection. (2008) ;68:285e292. 85.

[60] Prieto J, Kilpatrick C, Randle J. Chapter Two - (2014) Infection Prevention: Principles of Safe Practice in Healthcare. Boston: Academic Press; (2014).

[61] Rasslan O, Seliem ZS, Ghazi IA, El Sabour MA, El Kholy AA, Sadeq FM, et al. (2012) Device-associated infection rates in adult and pediatric intensive care units of hospitals in Egypt. International Nosocomial Infection
Control Consortium (INICC) findings. J Infect Public Health. (2012) ; 5: 394-402. doi:10.1016/j.jiph.2012.07.002.

[62] Rosenthal VD, Guzman S, Migone O, Crnich CJ. (2003) The attributable cost, length of hospital stay, and mortality of central lineassociated bloodstream infection in intensive care departments in Argentina: A prospective, matched analysis. Am J Infect Control. (2003) ;31: 475-480. doi:10.1016/j.ajic.2003.03.002.

[63] Rosenthal VD, Udwadia FE, Kumar S, Poojary A, Sankar R, Orellano PW, et al. (2015) Clinical impact and cost effectiveness of split-septum and single-use prefilled flushing device vs 3-way stopcock on central line associated bloodstream infection rates in India: a randomized clinical trial conducted by the International Nosocomial Infection Control Consortium (INICC). Am J Infect Control. 2015; 43: 1040-1045. doi:10.1016/ j.ajic.201 5.05.042.

[64] Rosenthal VD, Al-Abdely HM, El-Kholy AA, AlKhawaja SAA, Leblebicioglu H, Mehta Y, et al. (2016) International Nosocomial Infection Control Consortium report, data summary of 50 countries for (2010-2015): Device associated module. Am J Infect Control. (2016); 44: 1495-1504. doi:10.1016/ j.ajic.2016.08.007.

[65] Samuel, S. O, Kayode,O. O, Musa,O. I, Nwigwe,G.C, Aboderin A.O, Salami T.A.T, et al. (2010) Nosocomial infections and the Challenges of control in developing countries. African Journal Of Clinical And Experimental Microbiology. (2010) ;11(2):102-10.

[66] Sepideh Bagheri Nejad, Benedetta Allegranzi, Shamsuzzoha B Syed, Benjamin Ellis, Didier Pittet. (2011) Health-care-associated infection in Africa: a systematic review. Bull World Health Organ. (2011) ;89:757-765

[67] Shanelle Nelson, Patricia W. Stone, Sarah Jordan, Monika Pogorzelska, Helen Halpin, Megan Vanneman, et al. (2011) Patient Safety Climate: Variation in Perceptions by Infection Preventionists and Quality Directors. Interdisciplinary Perspectives on Infectious Diseases. (2011) ; Article id 357121. p7. doi: 10.1155/2011/357121.

[68] Sheng W-H, Chie W-C, Chen Y-C, Hung C-C, Wang J-T, Chang S-C. (2005) Impact of nosocomial infections on medical costs, hospital stay, and outcome in hospitalized patients. J Formos Med Assoc. (2005) May; 104(5):318-26.

[69] Sheth AM, Jani DS, Rangoonwala MM, Kadri AM. (2017). Assessing the awareness and practice of Hospital Acquired Infections (HAIs) among nursing staff of Civil Hospital, 
Rajkot, Gujarat, India. Inter J Res Med Sci. (2017) Jan 10; 3(8):1844-50.

[70] Tao L, Hu B, Rosenthal VD, Gao X, He L. (2011) Device-associated infection rates in 398 intensive care units in Shanghai, China: International Nosocomial Infection Control Consortium (INICC) findings. Int $\mathrm{J}$ Infect Dis IJID Off Publ Int Soc Infect Dis. (2011); 15: e774-780. doi:10.1016/j.ijid.2011.06.009.

[71] Tietjen L, Bossemeyer D, Mclntosh N. (2003) Infection Prevention Guideline for Healthcare Facilities with Limited Resources. Baltimore, USA: JHPIEGO Corporation; (2003).

[72] Tietjen L., Bossemeyer D. and Baltimore, NM, (2003). Guidelines for Healthcare Facilities with Limited Resources: United States of America. JHPIEGO Corporation. Maryland: United State of America.

[73] Vineya Rai, Cheong Yuet-Meng, Rosenthal, Victor Daniel, Mohd Shahnaz Hasan, Mazuin Kamarul Zaman, Mansor, Marzida, et al. (2016) Device-associated infection and mortality rates, bacterial resistance, and length of stay in hospitals of Malaysia: International Nosocomial Infection Control Consortium (INICC)'s findings. Can J Infect Control. (2016); 31: 107-112.

[74] World Health Organization. (2005). clean care is safer care: the first global challenge of the WHO World Alliance for Patient Safety. Geneva: Switzerland

[75] World Health Organization. (2009) Guidelines on Hand Hygiene in Health Care. (2009).
[76] World health organization. (2010) Infection prevention and control in health care: time for collaborative action. Regional Committee for the Eastern Mediterranean, EM/RC57/6. WHO. (2010). Available at: http://www.emro. who.int/Em_RC57_4_en.pdf/.

[77] World Health Organization. (2011) Report on the Burden of Endemic Health CareAssociated Infection Worldwide [Internet]. Geneva, Switzerland; 2011. Available from: http://www. who.int/about/ licensing/copy right_form/en/index.html.

[78] Yang C-C, Shih N-C, Chang W-C, Huang S$\mathrm{K}$, Chien C-W. (2011) Long-term medical utilization following ventilator-associated pneumonia in acute stroke and traumatic brain injury patients: a case-control study. BMC Health Services Research. (2011) Oct 31; 11(1):289.

[79] Xie D, Xiong W, Xiang L, Fu X, Yu Y, Liu L, et al.(2010) Point prevalence surveys of healthcare-associated infection in 13 hospitals in Hubei Province, China, 2007-2008. J Hosp Infect. (2010) ; 76: 150-155. doi:10.1016/ j.jhin.2010.04.003.

[80] Yallew WW, Takele AK, Yehuala FM. (2016) Point prevalence of hospital-acquired infections in two teaching hospitals of Amhara region in Ethiopia. Drug Healthc Patient Saf. (2016) ; Volume 8: 71 76. doi:10.2147 /DHPS .S10734412.

[81] Zhang X, Tong M-M, Zhang M-Z, Zhu H-P. (2015) Risk factors of nosocomial bloodstream infections in surgical intensive care unit. Int $\mathbf{J}$ Clin Exp Med. (2015); 8: 16682-16687.

Citation: Ahmad Salisu Aliyu, Ahmed Habibu Badawi, Nuru Yakubu Umar, Funmilayo Abubakar Sani, Bappah Baba Waziri. Epidemiological Study on Hospital Acquired Infections and Infection Prevention and Control among Health Care Workers in Specialist Hospital Bauchi State, Nigeria. ARC Journal of Public Health and Community Medicine. 2020; 5(3):1-13. DOI: dx.doi. org /10.20431/2456-0596.0503001.

Copyright: (C) 2020 Authors. This is an open-access article distributed under the terms of the Creative Commons Attribution License, which permits unrestricted use, distribution, and reproduction in any medium, provided the original author and source are credited. 